\title{
UUSI FILOSOFIAN OPPIKIRJA
}

rioiden totuudesta eivät liity kysymyksiin, jotka koskevat aineellisen maailman todellista luonnetta, vaan ne palautuvat kysymyksiin, jotka koskevat tieteellisten teorioiden menestystä kun pidetään silmällä joitakin käytännöllisiä päämääriä.

Hyvin usein käy niin, että sellaisissa filosofisissa teorioissa kuin Machin teoria totuus ja menestys samastuvat. Tällainen käsitys johtaa johdonmukaisesti loppuunajateltuna kantaan, jossa tietoisuudestamme riippumattoman todellisuuden olemassaolo kielletään tai siihen suhtaudutaan agnostisesti. Sillä, jos teoriat ovat vain 'symboleja ja merkkejä käytäntöä varten' miksi niiden pitäisi kertoa jotakin aineellisen maailman niistä puolista, jotka eivät kytkeydy kulloisenkin käytännön tarpeisiin. Lenin käsittelee pitkään tätä argumenttia Materialismi ja empiriokritisismi -teoksessa, ja se ei päde ainoastaan machilaisen positivismin kohdalla, vaan hyvin monen sellaisen opin kohdalla, jossa ajatellaan, että tieteellinen tutkimus on rationaalista täsmälleen silloin kun sillä on tai sille on välittömästi osoitettavissa jotkut käytäntöön liittyvät tavoitteet.

Ilkka Patoluoto
Reijo Wilenius - Pellervo Oksala - Lauri Mehtonen - Matti Juntunen: Filosofian kysymyksiä. Johdatusta filosofiseen ajatteluun, Gummerus, Jyväskylä 1976, 167 s.

Kouluopetukseen tarkoitetut filosofian oppikirjat ovat meillä jostakin syystä olleet poikkeuksellisen kehnoja. Urpo Harvan "Suuria ajattelijoita" on luettuaan paras viedä pikimmiten jätepaperikeräykseen ja Erkka Maulan "Filosofian aapinen" taas on enemmän edukseen tyylikukkasten kauhukabinettina kuin filosofian oppikirjana. Neliapilan Wilenius - Oksala Juntunen - Mehtonen kirjoittama uusi lukion filosofian opetuksen tarpeisiin aiottu teos toki hakkaa kirkkaasti nämä kaksi edeltäjäänsä; mutta siitä tuskin kannattaa lyödä rintoihinsa.

Muuan syy taitaa olla seuraava. Itsekritiikissään (eräässä monista!) ranskalainen Louis Althusser nimitti sukkelasti filosofiaa "luokkataisteluksi teorian alalla". Althusserin määritelmä filosofiasta ei tietenkään ole täsmällinen, mutta en puutu nyt asian siihen puoleen. Villakoiran ytimenä on se, että filosofiassa e i vo i olla puolueeton, ts. että filosofianopetus ei kykene antamaan adekvaattista kuvaa siitä, mitä filosofia on, jos rajoitutaan yleisesti selostamaan eri suuntauksia. On puhuttu "filosofian" kouluopetuksen tärkeydestä, vaikka kysymyksenä pitäisi ennemminkin olla: $\mathrm{mill}$ a is t a filosofiaa? Mutta tämän pulman ratkaiseminen taas jo edellyttää poliittisen taistelun tasolle kohoamista, eikä siitä tässä sen enempää.

"Filosofian kysymyksiä"-kirjan kirjoittajat myöntävät esipuheessaan: "Tarkkaavainen lukija huomaa kirjan olevan neljän enemmän tai vähemmän filosofisesti erilaillakin ajattelevan henkilön kirjoittaman". Kovin suurta tarkkaavaisuutta ei tuon havaitsemiseen sentään vaadittane, vaikka tekijät ovat yrittäneet säilyttää, niin kuin sanotaan, viileän objektiivisen kirjoitusotteen. Filosofia hajoaa tässäkin kirjassa eri näkökulmiksi, vaihtoehdoiksi. On helppoa kuvitella jokin Kari Palosen aatteista innostunut nuori lehtori, joka suosittelee tämän kirjan kimpussa puurtaville oppilaille trial and error -menetelmää kullekin sopivan filosofian esiinseulomiseksi. Hyvä on, mutta maailmankuva a ei tällä teoksella muodosteta - jos nyt nykyinen koululaitos kykenee vaikuttamaan oppilaiden maailmankuvan muotoutumiseen muulla tavalla kuin negatiivisesti.

"Filosofian kysymyksiä" on epätasainen. Laaksonpohjan muodostanee Reijo Wileniuksen kirjoittama ensimmäinen luku, "Ihminen

filosofisena ongelmana". Työssään Wilenius on nähtävästi konsultoinut ennen kaikkea itse aiemmin julkaisemaansa (ja uudelleenjulkaisemaansa) kirjaa "Filosofia ja politiikka". Niinpä saamekin lukea $\mathrm{mm}$. Hegelin - Marxin aristoteelisuudesta. Oudostuttaa, miksei Wilenius ole laajentanut tätä filosofianhistoriallista tutkimusmetodiaan: kas, Hegeliltä ja Marxilta löytyisi varmasti helposti myös platonisia, herakliittisiä, epikurolaisia, kartesiolaisia, spinozistisia jne. piirteitä. Etsivä löytää. Steiner-puffi sivulla 17 lienee taas vuorostaan mukana ennen kaikkea "viran puolesta".

Pellervo Oksalan laatimalla II luvulla ("Tieto ja todellisuus") on pluspuolellaan hyvä esitystapa. Ongelmat taritaan systemaattisella ja mielenkiintoa herättävällä tavalla. Mutta pukkejakin löytyy. Pahin sellainen on sivulla 79: sellaista materialismin ja idealismin väliin sijoittuvaa suuntausta kuin "neutraali monismi" (josta Oksala esittää ainoana esimerkkinä pesunkestävän materialistin Benedict Spinozan!) ei tietenkään ole olemassa. 
Mehtosen ja Juntusen kirjoittamat III ja IV luku ("Moraali ja yhteiskunta" sekä "Aikamme filosofisia suuntauksia") ovat, etenkin Juntusen kynästä lähtenyt jakso, teoksen parasta antia, jos kohta niiden kiireisesti tarjoama mitä moninaisimpien osa-alueiden katsaus lukijaa hengästyttääkin.

Koko kirjan yleisilmeelle on kuvaavaa, että ainoa viittaus "sosiaalisen elämän" (onko kyseessä termin "luokkataistelu" kryptogrammi?) vaikutuksesta filosofiaan löytyy yhteen kappaleeseen haudattuna sivulta 128 Juntusen tekstiosuudesta. Perspektiivivääristymä ei ole aivan vähäinen, sillä yhteiskunnallinen kehitys on filosofianhistorian $\mathrm{t}$ ä $\mathrm{rke}$ in lokomotiivi. Mutta näyttää nyt kerta kaikkiaan siltä, että pluralistisen aatevalikoiman taritseminen vaatii jo asian luonteen mukaisesti filosofian tarkastelua "sub specie aeternitatis".

"Filosofian kysymyksiä"-oppikirjaan tutustuminen vahvistaa vanhat käsitykseni: filosofiaan ei pääse perehtymään kunnolla muulla tavalla kuin sen historian kautta. On paljon jännittävämpää seurata esim. Kantin ponnistuksia rationalismin ja empirismin synteesin luomiseksi kuin etsiskellä Kantin systeemin irtileikattuja jäseniä erilaisten suuntausten rubriikkien alta. Vasta filosofianhistoria tarjoaa sen kontekstin, jossa filosofian problematiikka aktualisoituu elävällä tavalla. Pitää paikkansa, että filosofiassa on "ikuisia" ongelmia, mutta virhe tehdään, jos lähdetään tarkastelemaan niitä ikuisuuden kannalta.

Filosofian opetuksen kohentaminen vaatii varmasti muutakin kuin kunnon oppikirjoja. Klassikkojen käännöksistä olisi hyvä aloittaa.

Vesa Oittinen
PÄAMA on lausunut painavan. sanansa valtion tiedeneuvoston määrittelemistä painopisteistä (painopistealueiden tutkimuksen kehittämissuunnitelmista vuosille 1977 -1981). STK:n ja Teollisuuden Keskusliiton lisäksi on 31.5.1976 päivätyn lausunnan allekirjoittanut Elinkeinoelämän Tutkimuslaitos.

Pääoma aloittaa tarinansa melko kuluneella tempulla, jolla tosiasiat käännetään päälaelleen: Akatemian määrärahoja väitetään "maamme niukat resurssit huomioon ottaen" "suhteellisen suuriksi", vaikka ne ovat alle $10 \%$ luokkaa kaikista valtion tutkimusmenoista, jotka puolesțaan ovat $n$. puolet kaikista maamme tutkimusmenoista (toisena puolena yrityssektori). Kuitenkin jopa Kauppa- ja teollisuusministeriön suora tuki yrityssektorin tutkimus- ja kehittämistoiminnalle on Akatemian osuutta suurempi (1974 n. $11 \%$ ), puhumattakaan siitä, että huomattava osa itse valtion piirissä harjoitettavasta tutkimuksesta palvelee elinkeinoelämää.

Painopisteistä yleensä pääoma on sitä mieltä, että kehittämissuunnitelmat suuntaavat tutkimusta liikaa "yhteiskunta- ja taloustieteelliselle alueelle", joka on varsin altis tutkijoiden omille ideologioille". Pääomalla on "positiivinen vaihtoehto": "tutkimustoiminnan painopistettä /tulisi/ pyrkiä siirtämään hyödynnettäviin ja elinkeinoelämän kehittymistä palveleviin tutkimuksiin". Tätä periaatetta on pääoma edelleen konkretisoinut kunkin viiden painopistesuunnan kohdalla.

"Elinehtojen ja tuotantorakenteen tutkimuksen (P2) on jaosto suunnitelmassaan $\ldots$ rajoittanut tutkimusalueen liian suppeaksi" toteaa pääoma ja päätyy siihen, että koska tämän painopisteen tulisi palvella "voimakkaan ja kilpailukykyisen kansantalouden luomisessa" olisi rahat parasta panna yritysten R\&D-hommiin, eli "tutkimuslohkoihin": "voimavarat ja niiden kehittäminen, tuotantoprosessi ja tuotteet sekä teknologia".

"Demokratiaan ja tása-arvoisuuteen" (P4) suhtaudutaan arvokkaan arvovapaasti: olisi tutkittava "mitä käsitteet demokratia ja tasaarvoisuus toimivassa ja kehittyvässä yhteiskunnassa sisältävät".

Kansanterveyden tutkimiseen (P1) suhtaudutaan melko positiivisesti - tarvitseehan pääoma tervettä työvoimatavaraa. Huolena on vain se, että yhteiskuntatieteilijät sotkevat tämän(kin) alueen, niinpä yhteiskuntatieteille määritellään passiivinen osa: "poikkitieteelliset' 'impulssit tulkoon vain lääketieteen puolelta.

"Työsuojelututkimus" (P5) on saanut laajimman käsittelyn. Ensinnäkin pääoma olisi halunnut laajemman tutkimusalan, jossa oltaisiin tutkittu "työelämää säätelevää normistoa", "konfliktitilanteita" ym. industrial relations-tutkimusta. Toisaalta "työsuojelututkimuksen kehittämissuunnitelmassa on sekoitettu keskenään työsuojelututkimus ja yhteiskuntapolitiikka" - työsuojelu on käsitety liian laajaksi ("yhteiskunnalliseksi"); työsuojelututkimus ei saa olla "yhteiskuntatutkimusta". Työsuojelu näyttää olevan osa tuotekehittelyä; se on tekniikkaa ynnä vähän lääketiedettä. Sillä ei ole mitään tekemistä "yhteiskunnan" kanssa.

"Ympäristönsuojelua sekä luonnonvaroja ja ympäristöä säästävien menetelmien ja tuotteiden kehittämistä koskevaa tutkimusta" (P3) pääoma periaatteessa kannattaa. Sitä vain harmittaa se, että "ympäristösuojelusta on tullut muotisana, joka yhdistetään usein tieteelliseen tutkimukseen rahoituksen helpottamiseksi, koska kukaan edistyksellisesti ajatteleva ei voi asennoitua kielteisesti ympäristötutkimuksiin tulematta leimatuksi ympäristösuojelun vastustajaksi" - 